\title{
THE 1991 WORLD MICROCOMPUTER CHESS CHAMPIONSHIP
}

\author{
ICCA Communication
}

by David Levy

The $11^{\text {th }}$ World Microcomputer Chess Championship will take place in Vancouver, Canada from May $1^{\text {st }}$ to $9^{\text {th }}$, 1991. When subscribing, please use a copy of the entry form below.

\section{ENTRY FORM WORLD MICROCOMPUTER CHESS CHAMPIONSHIP VANCOUVER, CANADA \\ May $1^{\text {st }}$ to $9^{\text {th }}, 1991$}

Authors(s) of the program:

Name and address for correspondence:

Work telephone: Home telephone:

Name of program:

Tournament record:

Number of games played:

Programming language: Size of program:

Size of openings book (positions):

Hardware being used in the tournament:

Microprocessor(s)

Which of the authors will come to Vancouver? Clockspeed

FOR MANUFACTURERS' GROUP ONLY

The above information must be supplied for all of your machines except a machine in the "unlimited" category.

How many machines are you entering? (delete as applicable) $\quad \begin{array}{lllll}1 & 2 & 3 & 4\end{array}$ Is one of these machines in the unlimited category?

YES NO

Total entry fee: $\$$

Note that manufacturers who enter the unlimited category must pay $\$ 4,000$ U.S. irrespective of whether they enter $0,1,2$ or 3 additional machines. Other manufacturers must pay $\$ 1,000$ per machine. Non-Amateurs in the software group must pay $\$ 1,000$ (only one machine allowed). Participants living in countries where the currency is not convertible, e.g., eastern Europe, do not pay any entry fee. Amateurs also have free entry.

Date of entry: Signature:

At the discretion of the ICCA certain amateur programmers may receive free hotel room and food.

Entries and enquiries should be addressed to:

David Levy

44, Aylestone Avenue,

London NW6 7AA,

England

Telephone: $\quad+44814592388$

Fax: $\quad+44814596422$

Entries should arrive not later than April $1^{\text {st }}$ (Manufacturers' Group) or March $18^{\text {th }}$ (Software Group).

Participants who would like to apply for a limited amount of financial support to enable them to travel to Vancouver should write to David Levy. 